\title{
Evidentiary value of archaeological evidence: Judicial approach of the Supreme Court of India with special reference to M. Siddiq (Dead) through legal representative vs. Mahant Suresh Das (1 SCC 1)*
}

DOI: 10.15175/1984-2503-202113201

\author{
Tarkesh J. Molia* \\ Vikash Kumar Upadhyay $^{* * *}$ \\ Arpit Sharma ${ }^{* * * *}$
}

\begin{abstract}
Ram Janmbhoomi (birth place of Lord Rama) is the most controversial dispute of the independent India. The dispute was existing in pre-independence era but after independence dispute has changed the direction and condition of Indian political system. There was claim that mosque was built after the demolition of Ram temple. This dispute was so intense that it brought the incident of demolition of mosque in 1992. After demolition suit was filed from both the side: Muslim and Hindu. The decision of apex court on civil suit came after 27 years. The apex court took the cognizance of Archaeological Survey of India (ASI) report to decide the claim of parties. This paper aims to give a brief background of Ramjanmbhoomi dispute; explore evidentiary value of expert opinion; whether archaeology is science or art; to evaluate the evidentiary value of archaeological report prepared by ASI through evacuation in the judgement.
\end{abstract}

Keywords: Archaeology; Supreme Court; evidentiary value; temple; mosque.

\footnotetext{
* 12020 SCC number 1 (Supreme Court Cases, number 1, 2020). SCC is an Indian Law Journal which report judgments from the Supreme Court of India.

${ }_{* *}$ Associate Professor at the Institute of Law, Nirma University, India, Ph.d from Saurashtra University, Rajkot. Specialization in Constitutional Law, Human Rights, Comparative Constitution. Research areas of Interest: Constitution, Human Rights. E-mail: tarkeshpatel1@gmail.com. (10 https://orcid.org/0000-0003-4470-5056

${ }^{* * *}$ Professor Assistente no Instituto de Direito da Universidade Nirma, Índia. PhD pela Babasaheb Bhimarao Ambedkar University (A Central University), Lucknow. Tem especialização em Direito Constitucional, Direito Administrativo e Direitos Humanos. Áreas de interesse de pesquisa: Direito Constitucional, Direitos Humanos e Jurisprudência. E-mail: vgupadhyay@gmail.com. (1) https://orcid.org/0000-0001-7791-9590

****x Assistant Professor at the Institute of Law at Nirma University, pursuing Ph.D. from Gujarat National Law University, Gandhinagar. Specialization in Labour Law, Real Estate Law, Corporate Law. Research areas of interest: Labour Law, Corporate Law, Real Estate Law. Email:arpitt.sharmaa@gmail.com.

(1) https://orcid.org/0000-0001-8883-260X
} 

intermédio do respectivo representante legal, contra Mahant Suresh Das (2020) 1 SCC"

\section{Resumo}

Ram Janmbhoomi, a saber, localidade de nascimento de Lord Rama, está na origem do litígio mais controverso da Índia desde a independência do país. Essa contenda existia desde o período colonial, mas foi após a independência que ela alterou profundamente o sistema político indiano. Havia uma reivindicação segundo a qual a mesquita fora construída após a demolição do Templo Ram. O litígio era tão intenso que, em 1992, engendrou o incidente da demolição da mesquita. Em decorrência desta demolição, ações judiciais foram impetradas pelas duas partes em conflito, a saber, muçulmanos e hinduístas. A decisão da Suprema Corte sobre a ação civil ocorreria 27 anos depois. Para pronunciar o seu veredito, a Suprema Corte tomou conhecimento do relatório da Agência Arqueológica da Índia (ASI). Este artigo propõe-se a apresentar um breve histórico do conflito de Ramjanmbhoomi, a avaliar o valor probatório da opinião dos peritos, a saber se a Arqueologia é uma ciência ou uma arte e, por fim, a avaliar a qualidade probatória do relatório arqueológico elaborado pela ASI no âmbito do referido julgamento.

Palavras-chave: Arqueologia; Suprema Corte; valor probatório; templo; mesquita.

El valor probatorio de las pruebas arqueológicas: el enfoque judicial del Tribunal Supremo de la India con especial referencia a "M. Siddiq (fallecido) a través de su representante legal frente a Mahant Suresh Das (2020) 1 SCC"

\section{Resumen}

Ram Janmbhoomi (lugar de nacimiento del dios Rama) es el objeto de disputa más controvertido de la India independiente. La discusión sobre su pertenencia es anterior a la independencia del país, pero la independencia ha cambiado la dirección y condición del sistema político indio. Por una parte, se alegaba que la mezquita fue construida tras la demolición del templo de Rama. El conflicto llegó a tal nivel de intensidad que provocó la demolición de la mezquita en 1992. Después de este incidente, ambas partes implicadas musulmanes e hinduistas-, interpusieron sendas demandas. La decisión del Tribunal Supremo sobre esta causa civil tardó 27 años en llegar. El Tribunal Supremo tuvo en cuenta el informe del Servicio Arqueológico de la India para pronunciar su veredicto. El objetivo de este artículo es ofrecer un breve resumen de los antecedentes del conflicto de Ramjanmbhoomi, explorar el valor probatorio de la opinión de los expertos, determinar si la arqueología es una ciencia o un arte, y analizar la fuerza probatoria del informe arqueológico elaborado por el Servicio Arqueológico de la India para la resolución del proceso.

Palabras clave: Arqueología; Tribunal Supremo; valor probatorio; templo; mezquita.

La valeur probante des preuves archéologiques : l'approche judiciaire de la Cour suprême de l'Inde dans l'affaire «M. Siddiq (décédé) par l'intermédiaire de son représentant légal contre Mahant Suresh Das (2020) 1 SCC »

\section{Résumé}

Ram Janmbhoomi, à savoir le lieu de naissance de Lord Rama, est à la base du litige le plus controversé de l'Inde indépendante. Ce différend existait avant l'indépendance, mais c'est après celle-ci qu'il a modifié en profondeur le système politique indien. Une revendication existait selon laquelle la mosquée avait été construite après la démolition du temple Ram. Le litige était si intense qu'il a entraîné l'incident de la démolition de la mosquée en 1992. À la suite de cette démolition, des poursuites ont été engagées par les deux parties au conflit, à savoir les musulmans et les hindous. La décision de la Cour suprême sur l'action civile est intervenue 27 ans plus tard. La Cour suprême a pris connaissance du rapport des Services archéologiques indiens (ASI) pour prononcer son verdict. Cet article vise à proposer un bref historique de ce conflit du Ramjanmbhoomi, à évaluer la valeur probante de l'opinion des experts, à savoir si l'archéologie est une science ou un art, et enfin à évaluer la qualité de preuve du rapport archéologique préparé par l'ASI dans le cadre de ce jugement.

Mots-clés : Archéologie ; Cour Suprême ; valeur probante ; temple ; mosquée. 


\section{考古证据的证据价值：印度最高法院对印度教拉姆神出生地清真寺拆除案的裁判方法}

\section{摘要:}

Ram Janmbhoomi (拉姆神的出生地) 是独立印度最具争议的争议。争端发源于印度独立前时代，但在独立 后，争端改变了印度政治制度的方向和状况。争端的缘起是有人指控说清真寺是在印度教拉姆神庙拆除后建造 的。这场争端是如此激烈，以至于在 1992 年引发了清真寺拆除事件。穆斯林和印度教徒双方提起拆除诉讼。 印度最高法院针对此项民事诉讼的裁决是在 27 年之后作出的。最高法院以印度考古学会(ASI)的报告为依据， 裁定当事双方的主张。本文的目的是简要介绍拉姆神出生地之争的背景。探讨专家意见的证据价值 一 考古学 是科学还是艺术? 作者评估了印度考古学会 (ASI) 撰写的考古报告及其证据价值。

关键词：考古学；最高法院；证据价值；印度教神庙；伊斯兰教清真寺。

\section{Introduction}

In 1528 a mosque was built by Mir Baqi, a Mughal commander during the regime of first Mughal emperor Babur. It was built during the regime of Babur therefore, it was called as Baburi Mosque also. Some Hindu groups claimed that this mosque was built on the place, where earlier a temple was existing. These Hindu groups believed that this was not mere a simple temple but the birthplace of Lord Rama. The Hindu Groups believed that this Lord Rama temple was demolished to construct the mosque. This dispute was in existence before the independence of India. In 1885, Mahant Raghubir Das filed a plea in the Faizabad District Court to construct a canopy on the outer premise of Babari Mosque. The court rejected the filed plea. This dispute was continued. After independence from British rulers on December 1949, idols of Lord Rama Lalla (child version of Lord Rama) was placed in the disputed mosque. The District Magistrate Nair in order to prevent the communal violence locked the mosque. 1950, Mahant Gopal Simla Vishard filed a suit in the Faizabad District Court to get permission for right to worship idols of Lord Ram Lalla. In 1959 the Nirmohai Akahra filed a petion before the district court for possession of the disputed site. Later on the Sunni Central Waqf Board also filed a suit for possession of site. On February 1986, the District Court of Faizabad passed the order to open the disputed site for the Hindu worshippers. This made the situation worst and more communal tension was likely to happen. On August, 1989, the Allahabad High Court passed the order for maintenance of status quo with respect to disputed structure. On December 6, 1992 the Babri Mosque was demolished by Karsevaks. This filled atmosphere of entire nation with communal tensions. The parliament passed the legislation "Acquisition of Certain Area at Ayodhya Act, 1993" for acquiring the disputed land. Numerous writ petitions were filed before the Supreme Court, 
The Supreme Court under Article 139A transferred the writ petitions to the Allahabad High Court, where already some petitions were pending. On April 2002 the High Court of Allahabad started the hearing on the question who owns this dispute site. This questions also comes with two ancillary questions: Had Babur indeed destroyed a Hindu temple in Ayodhya, and, if so, had he built his mosque on the same spot? (BERNBECK; POLLOCK, 1996). On September 2010, the High Court of Allahabad with a majority of 2:1 gave a three way formula for division of dispute area between three contesting party that is Sunni Waqf Board, Nirmohi Akhara and Ram Lalla. On the appeal against the judgement of Allahabad High Court, the Supreme Court, styed the judgement. The Chief Justice of India J.S. Khear had suggested for out of court solution among the contesting parties in 2017 . The Supreme Court set up a constitutional bench of 5 judges comprising of Ranjan Gagoi CJI; S.A. Bobade, D Y Chandrachud, Ashok Bhusan and SA Nazeer JJ. on January 2019. The Supreme Court gave the judgment on 09 November 2019 (INDIAN, 1 SCC 1, 2020).

\section{Review of Literature}

The author in this paper specifically stated that the lesser importance was paid towards interpretation of substantive law whereas the judgment more or less under political influence (RAMNATH, 2011). The question in this paper mainly revolve around the title of property on one hand or on the other side the identity. In this work highlighted the procedural and evidentiary impulses. It is also not difficult to locate through the point that the Archaeological Survey of India (ASI) report is the authorized account or that "Hindus" are treated as an identical category in law or that the court mentioned in one of the suits that was pleaded five Muslims living in the area mentioned in the provision of the Civil Procedure Code as representation of the Muslim community (INDIAN, 1908, Order I, Rule 8).

The researcher in this article critically analysis the point of religious belief and justice wherein religion is involved into it (GOPINATH, 2010). This article basically analyzes the judgment pronounced by Hon'ble Allahabad High Court ${ }^{1}$ to cover the title of the dispute on the land (birth-place). In this work the question arose by the author with respect to the birthplace and landownership is more fearsome about this is that by making coterminous, it appears to have created the possibility of treating birth as the grounds for legitimizing

\footnotetext{
${ }^{1}$ Coram of the Judges are Hon'ble Justice Sibghat Ullah Khan, Hon'ble Justice Sudhir Agarwal, Hon'ble Justice Dharam Veer Sharma, J.
} 
ownership. The author also pressed upon the legal exculpation of the "beliefs and faith" of Hindus by the Hon'ble court has not solely legitimized retroactively the demolition of the Babri Masjid, it has covered the way for legally balancing birthright with other substantive rights, on the basis of religious grounds, all of which hold the startling possibility of fading, even nullifying, the rights of minority groups in India.

The author specifically focused on the critical review of the judgment and interpret the judiciary viewpoint with respect to point where Lord Rama born (GUPTA, 2010). The author refers the point from the judgment where Justice Agarwal specifically mentioned it is impossible because the time varied from thousand years. It is to be said where he was actually born and can this be decided by a court of law by collecting positive evidence on this aspect and crucial point to decide the claim of the land.

\section{Meaning of Expert Opinion}

Section 3 of the Indian Evidence Act (Hereinafter called 'IEA') (INDIAN, 1872) gives the definition of Fact which means and includes- "anything, state of things or relation of things, which may be perceived by the senses". Section 45 of allows to take the opinion of expert on any relevant fact. Section 3 also defines the Relevant Fact as a fact which is connected with the one in any way asper the IEA. The word 'expert' or 'expert opinion' has not been defined directly in the IEA or any Law. Section 45 IEA only states about the persons who are especially skilled in foreign law, handwriting, science or finger impressions are the expert. ${ }^{2}$ These persons can give their evidence on the 'fact'. As per the definition of fact it includes from state of things or relation of things or mental condition which may be perceived by the senses. ${ }^{3}$ The Supreme Court has defined the expert as a person who has acquired special knowledge of the particular subject due to study or practice or observation. ${ }^{4}$ The expert must have devoted a substantial amount of time and study for the subject. ${ }^{5}$ The duties

\footnotetext{
${ }^{2}$ Opinions of experts- "When the Court has to form an opinion upon a point of foreign law or of science or art, or as to identity of handwriting [or finger impressions], the opinions upon that point of persons specially skilled in such foreign law, science or art, [or in questions as to identity of handwriting] [or finger impressions] are relevant facts" (INDIAN, 1872, Section 45).

${ }^{3}$ S. 3 of IEA 1872, defines fact: "Fact means and includes-

(1) anything, state of things, or relation of things, capable of being perceived by the senses;

(2) any mental condition of which any person is conscious."

${ }^{4}$ State of Himachal Pardesh vs. Jailal AIR 1999 SC 3318

${ }^{5}$ State vs. S.J. Choudhary AIR 1996 SC 1491
} 
of the expert witness is to provide information to the court, with respect to issues, which may help the court to interpret the information, which is not in the knowledge of the court. ${ }^{6}$

In this case the relevant fact was whether the mosque was constructed after demolition of temple and whether the underlying structure was temple. To ascertain this the opinion of experts in archaeology need to be taken.

\title{
Value of Expert Opinion
}

The evidence based on the expert opinion must be taken into account with great caution. The opinion of an expert on facts should be admitted only when there is question with respect to science or art. For example, if the evidence produced by expert is just an opinion but not supported by any reason, it should not be taken into account by the court. ${ }^{7}$

The statements in the ASI report constitutes the opinion of an expert. This opinion is by an expert governmental agency in the area of archaeology.

The expert opinion can be taken on subject of science or art. Now it needs to check whether the Archaeology is a disciple of Science or Art?

\section{Whether Archaeology is Science or Art}

Justice Sudhir Agagrwal said that

\begin{abstract}
Archaeology provides scientific factual data for reconstructing ancient historical material, culture, understanding. Archaeology [...] is a multi-disciplinary scientific subject and requires a team of workers for effective results. Excavation of ancient sites is one of the major works of Archaeologists. As it is a scientific discipline, it uses scientific methods in its working (INDIAN, 1 SCC , 2020, p. 488).
\end{abstract}

Archaeology is a science which comes from multidisciplinary or transdisciplinary. The evidences based on archaeology comes on scientific learning, the wisdom of experience. This archaeology cultivates a trained mind. This discipline combines the knowledge of history, sociology and anthropology and make it more strength. It is has the feature of art and science both. As a branch of science it evaluates objectively and as art it work on the vision to get knowledge based on the histories of era. The value of archaeology cannot be diluted on the argument that it is a weak form of evidence (INDIAN, 1 SCC , 2020, p. 679). Taking the importance of archaeology, the High Court of Allahabad has issued the order of

\footnotetext{
${ }^{6}$ Regima vs. Turner, (1975) 1 Q.B. 834; Prem Sagar Manocha vs State (NCT of Delhi)

${ }^{7}$ AIR 1964 SC 529
} 
evacuation of the disputed place to take the archaeological evidence as expert evidence under section 45 of IEA.

\section{High Court's Order for Excavation}

The High Court of Allahabad proposed to carry out an excavation by ASI. On 5-032003, Director General of ASI constituted a fourteen-member ASI team The ASI took a preliminary survey by a Geo-Radiology System (GRS) survey. The GRS report reflected about a variety of anomalies. The exact nature of these anomalies could be determined only on the basis of archaeological excavation. The Court further gave green signal to ASI for excavation. The High Court passed a detailed directions to keep the records coming from excavation like the contesting parties will be present at excavation site, the material will be kept under lock and seal, the court would be informed periodically about the progress of excavation, the ASI has to maintain a regular register to maintain the records etc. The High Court also ensured that there must be adequate representation of both community in terms of ASI team and as well in the engagement of labour. The process of excavation was also video graphed. The ASI submitted its final report on 22-08-2003 (INDIAN, 1 SCC, 2020, p. 588).

The purpose of the High Court for excavation was to enable the court to get the scientific information based on a scientific investigation. The other object was to check whether there is any underlying temple structure on which a mosque was constructed.

\section{Findings of Archaeological Survey of India Report}

The Archaeological excavation finds evidences which indicates that the beginning of civilisation took place here from second century $\mathrm{BC}$. The finding also revealed that there was a pre-existing underlying structure dating back to the $12^{\text {th }}$ century. The structure has a large dimension which is based on 85 pillars. On a preponderance of probabilities, it looks as Hindu religious structure. There is existence of a circular shrine with a Makara parnala, it indicates about the Hindu worship dating back to $10^{\text {th }}$ century. The mosque has foundation on a pre-large existing structure (INDIAN, 1 SCC, 2020, p. 1205).

However, the ASI reports showed the existence of a destructed pre-existing but it is not able to states the reasons for destruction in its report. It is not able to give answer to the question whether the earlier structured was demolished for construction of mosque. As per the $\mathrm{ASI}$ report the structure was dated back to $12^{\text {th }}$ century but it could not be able to give 
answer about a time gap of four centuries between the underlying structure and construction of mosque. The ASI report also could not be able to answer whether the residue of the preexisting structure were used in construction of mosque or not? (INDIAN, 1 SCC , 2020, p. 1206). The ASI report could not explain is there any nexus between black kasauti pillars used in construction of mosque and the structured beneath the earth.

The Supreme Court has said in this case that the ASI report must be read with the following caveats:

(a) The excavation revealed the presence of a circular Shrine, dating back to7th to $9^{\text {th }}$ century and underlying structure belongs to $12^{\text {th }}$ century. The difference of time period is three to five centuries between the circular Shrine and underlying structure.

(b) The claim that the underlying structure was a temple dedicated to Lord Ram was not supported by any particular evidence.

(c) More Importantly the ASI report has not precisely opined on whether disputed mosque structure was constructed on the demolition of a pre-existing Lord Ram temple. The court has understood this inability and said that it would really a great difficulty to get hindered years back and find very precisely whether there was any demolition for construction of mosque or the earlier building may be collapsed due to natural forces also (INDIAN, 1 SCC , 2020, p. 1206).

\section{Supreme Court on Evidentiary Value of Archaeological Evidence}

The weight of expert evidence depends on the nature of science on which it is based. Where the science in question requires necessary elements of verification and objective analysis, the expert evidence must have such necessary elements. A more advanced and perfect science will have less chance of incorrect opinions while if the science is less advanced the risk of incorrect will be more likelihood. If we take the example of expert opinion based on fingerprints the risk of incorrect opinion is very less, while the expert opinion on handwriting has very much likelihood to be incorrect because it is not as developed. The Supreme Court has rejected argument that as the expert opinion on hand writing is weak, similarly the expert opinion on the archaeological evidence is weak because it is not a developed science. The court said that while accessing the evidence based on archaeology it is necessary to see whether the scientific measures was taken into account or not. The process of excavation must be documented properly in electronic and 
conventional forms. What is excavated and found is a fact. This fact must be related with data by archaeologist. The process of drawing inference from the data is necessary part of archaeology but to reject this process on the basis that it is speculative and hypothetical will be a disservice for archaeology and the process of excavation. In this case no party has questioned the independence of ASI team which was undertaken the exercise of excavation. While taking the evidence of archaeological evidence the ASI report should be read in its entirety. It would be very unwise to reject the conclusion of archaeological evidence which is prepared by an expert team which carried out excavation under the orders of a High Court and very judiciously investigated the recoveries from different perspectives. However, the archaeological evidence must be taken contextually.

The evidence based on the archaeology was questioned on the ground that archaeology is an inferential science. In addition to this one more argument was that it is a branch of social science which is distinct from natural science due this it cannot be based on verifiable hypotheses. Particularly, in this case the ASI had prepared its report in 15 days in a hurried manner. This objection does not help to say that archaeological evidence cannot be taken, if the excavation was done with full care and in scientific way the evidences based on archaeology will be valuable. However, the Supreme Court has discarded these arguments that the report was prepared in hurried way and without taking care.

\section{Judicial Power and Historical Wrongs}

The Apex court also expressed its opinion whether the judiciary has the power to question on historical wrongs and can give the remedy for it. The Apex Court said that it is not possible to use law as instrument go in past and give a remedy to every person who is disagree with the action of the past. Even the court cannot take the cognizance of any rights and wrong committed in the past unless it is not proved that after taking cognizance of any historical wrongs the outcome of the court is enforceable. If it would be enforceable then the court may take the cognizance of historical wrongs. The court can take cognizance only when the injuries suffered in the previous legal regime has been recognised by the subsequent sovereignty. In absence of such recognition, the court cannot compel the subsequent Sovereign to recognize the historical wrongs and give remedy for it. Further, the municipal courts have jurisdiction to investigate and ascertain only those right which has been recognised by the new Sovereign through any legislation, agreement or any other instruments. This agreement or recognition by new Sovereign may be express or implied as 
well. The municipal courts have to check whether the new Sovereign has recognised the rights in question or not, if recognised then only the municipal courts can have jurisdiction to take the cognizance. The burden of proof will lie on the parties which is claiming the right. The judicial authority cannot take the claims which comes from the actions of ancient rulers, the law does not give the answer to these claims. The history has replete actions which are immoral and even it may trigger the violence today also. The adoption Indian Constitution worked as watershed moment where, We, the people of India, moved away from religious based or colour based identity (INDIAN, 1 SCC , 2020, p. 993; 995-996).

\section{Supreme Court on Finding of Title Based on Archaeological Findings}

The Supreme Court has answered to this question whether the title can be established on the basis of archaeological findings. The court said in this case there was a time gap between $12^{\text {th }}$ century to which the beneath structure is dated and the construction of mosque of $16^{\text {th }}$ century. There is not any evidence which can be shown in context of human history between the $12^{\text {th }}$ century and $16^{\text {th }}$ century. There is also no evidence to prove the cause of destruction and whether the pre-existing structure was demolished to construct a mosque. Therefore, a title cannot be established by archaeological findings which were made by the ASI.

So, we may say that the title of property cannot not be established on the archaeological findings (INDIAN, 1 SCC 1, 2020, p. 1224).

\section{Conclusion}

The Supreme Court concluded that the archaeological evidence could not prove that whether the mosque was constructed after demolition of temple. The Court further said it could not be also proved that whether the underlying structure was a temple. The court has applied the 'doctrine of justice, equity and good conscience' to resolve this dispute. The Court has exercised this power given under Art. 142 of the Indian Constitution. It empowers the Supreme Court to pass any order or decree for giving a complete justice. The court has used this power under the 'doctrine of equity, justice and conscience' to do complete justice. The principle of justice, good and concise plays an ancillary role when the statutory provisions are inadequate to give remedy, then the court may take help of this principle. This principle supplements the justice. The court cannot refuse to give remedy on the ground that laws are inadequate. The court may develop the new tool to deliver the justice. One of them 
tool is justice equity and good concise. The court has power to craft relief based on equity, justice and good concise. Therefore, the Supreme court has used the power given under Article 142 to do give complete justice (INDIAN, 1 SCC 1, 2020, p. 1239). The Court said that possession of the inner and outer courtyard will be given to a trust created by central government and the Central Government within three months of this decision shall formulate a scheme for the construction of temple. The possession shall continue vest in the hands of Central Government. The court further states that a suitable plot of 5 acers will be given to Sunni Waqf Board in Ayodhya (INDIAN, 1 SCC 1, 2020, p. 1240-1243). The Supreme Court had taken the literature and other evidences in support of this judgement. However, the Supreme Court unequivocal accepted that the Archaeology is a science and under the Section 45 of IEA. Therefore, the expert opinion on the archaeological findings can be taken and the evidentiary value will be same as it is for other discipline of science or art. The argument that it is a multidisciplinary discipline does not dilute the evidentiary value of it rather it is the strength of the archaeology.

\section{References}

BERNBECK, Reinhard; POLLOCK, Susan. Ayodhya, Archaeology, and Identity. Current Anthropology, Chicago, v. 37, n. 1, p. S138-S142, 1996.

GOPINATH, Arunima. Ayodhya Verdict: Bad Theology, Without Justice. Economic \& Political Weekly, Bombay, v. 45, n. 41, Oct. 9, 2010.

GUPTA, Anupam. Dissecting the Ayodhya Judgment. Economic \& Political Weekly, Bombay, v. 45, n. 45, Dec. 11, 2010.

INDIAN. Indian Evidence $1872 . \quad$ Act. Available at: https://legislative.gov.in/sites/default/files/A1872-01.pdf. Accessed on: Feb. 18, 2021.

INDIAN. The Code of Civil Procedure. 1908. Available at: https://legislative.gov.in/sites/default/files/A1908-05.pdf. Accessed on: Dec. 12, 2020.

INDIAN. Supreme Court of India. M. Siddiq (Dead) through Legal Representative vs. Mahant Suresh Das. Supreme Court Cases, n. 1, 2020.

RAMNATH, Kalyani. Of Limited Suits and Limitless Legalities: Interpreting Legal Procedure in the Ayodhya. National University of Advanced Legal Studies Law Journal Judgment, Kochi, v. 5, n.1, 2011. 